\title{
Techno- Economics of a Hybrid Photovoltaic Wind Turbine
}

\author{
Cawas Phiroze Nazir \\ Consulting Engineer Kolkata 700019, India
}

\begin{abstract}
To improve the overall energy production from the wind turbine and lower the levelized cost of energy (LCOE), an innovative approach for the design of a hybrid solar-wind turbine (HSWT) is proposed. The present concept is based on installing arrays of solar panels on the south-facing facade of the turbine tower to generate electricity from sunlight. The hybrid offers greater benefits compared to separate systems. An example is given of an offshore WT with a rated capacity of 4.7 MW forming part of a $600 \mathrm{MW}$ wind farm in the North Atlantic. The $100 \mathrm{~m}$ high tower is covered with $465 \mathrm{PV}$ panels of $340 \mathrm{~W}$ capacity. For evaluation, the gross resource of each renewable is estimated considering the specifications of the available data In the discussion, the LCOE's of wind and the hybrid solar-wind combination are compared. From the results, it is clear that HSWT offers a reduced LCOE, even after allowing for shading losses from the blade, and a much steadier production of energy. The introduction of HSWT would help to make wind farms a more cost-effective and competitive source of clean energy.
\end{abstract}

Keywords : Solar; wind-turbine; hybrid; tower; LCOE 


\section{Introduction}

Global warming is beginning to take a huge toll on our planet. It is important to halt the build-up of greenhouse gases (GHG) to avert some of the most potentially disastrous effects. This requires that we start reducing the amount of GHG pollution we release into the atmosphere. The solution has been to develop greener technologies that depend on non-fossil fuels. Wind power is one such technology, with wind farms making a significant contribution to our global electricity grid. With wind power increasingly moving out to sea, the current generation of wind turbines (WT) has been upscaled into a multi-megawatt range in terms of power. However, the energy benefit from these large turbines is offset by the increased mass and cost of energy produced. To make wind power more attractive, a hybrid solar wind turbine system is proposed that utilizes both solar and wind energy. This innovative approach involves installing photovoltaic (PV) panels along the currently unproductive tower face to produce solar energy. This combines solar power and wind resulting in a single point of conversion, leading to reduced capital expenditure, and an increase in annual energy production. Previous attempts have been made to combine wind and solar. Southwest Windpower, Brown [1] has introduced a hybrid solution for small wind power plants where the solar panels are mounted on the wind turbine tower. In another design, Lopez et al [2] have proposed placing floating PV panels between the free spaces amidst the offshore wind turbines. However, in most hybrid solar wind power plants, the solar plant is ground-mounted. One example is the $30 \mathrm{GW}$ Gujarat Hybrid Renewable Energy Park where electricity from both solar panels and wind turbines is being employed. [3] see Fig. 1. Many researchers have carried out work on hybrid energy systems related to different 


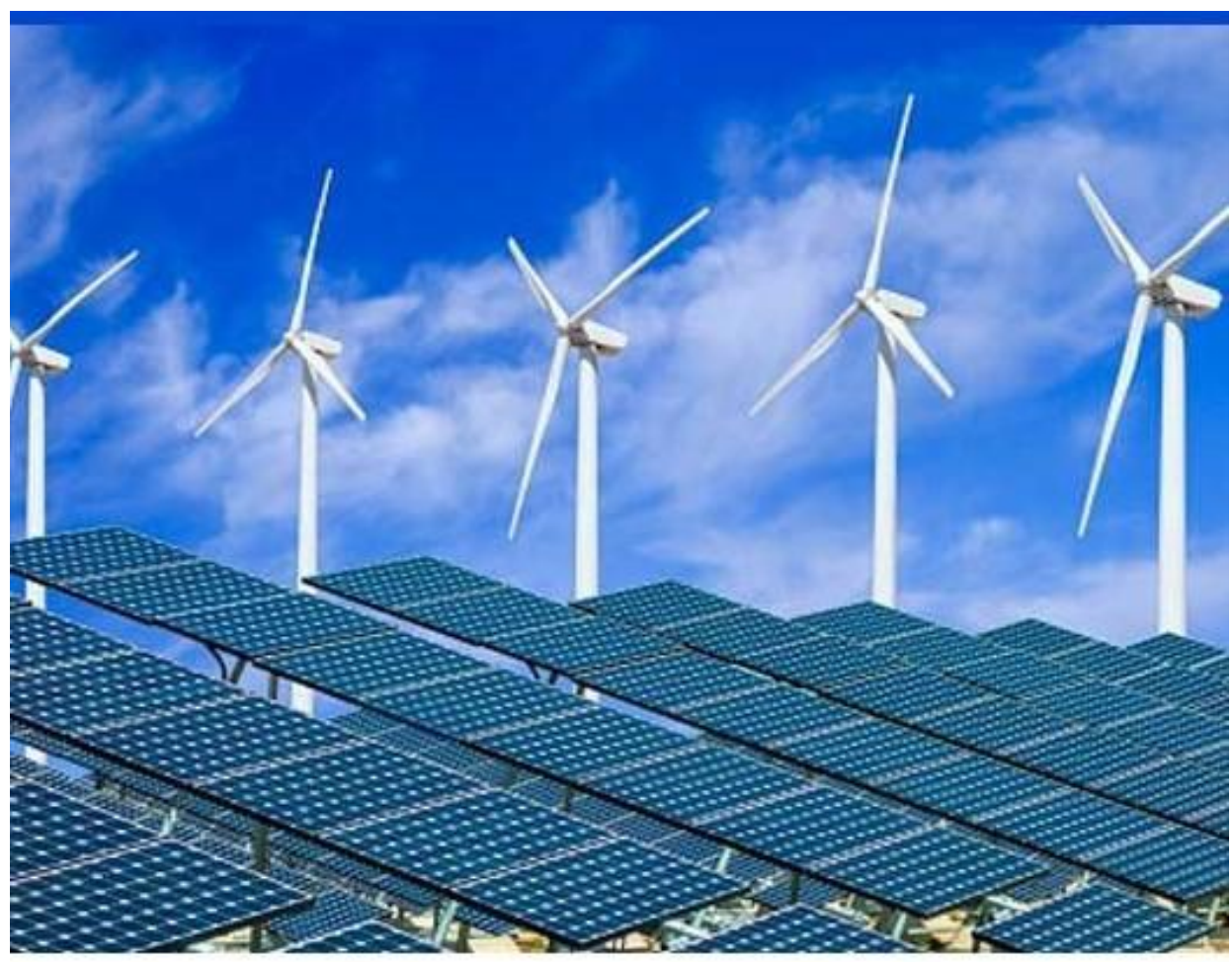

Fig. 1 Hybrid Solar-Wind Energy Park

parameters of performance and optimization [4-8]. Wind turbines are machines that harness wind energy. Modern wind turbines (WT) comprise a horizontally configured drive train having three blades attached to an upstream facing rotor. The rotor is supported at the tower top using a rotor bearing, Willey [9]. To increase the power capacity of WT, the size of blade areas has been increased and taller towers to capture wind at higher altitudes have been implemented. Studies have shown that every $10 \mathrm{~m}$ up, the wind speed can increase by $20 \%$ and the power output by $34 \%$.Kohiowind [10 ].

In this paper, the baseline for comparison purposes is the NREL 4.7 MW turbine for a hypothetical offshore-based wind farm of $600 \mathrm{MW}$ rated capacity in the North Atlantic ocean. For design, the 4.7 MW WT is designed as an HSWT based on the same design conditions. The innovation was analyzed to understand the potential impact on the Levelized Cost Of Electricity (LCOE) for future wind power plants. A typical schematic of a Hybrid Solar Wind Turbine (HSWT) showing a front view and side view is given in Fig.2. The paper is organized as follows: Section 2, gives a Combined Technology Overview that presents the hybrid solar-wind integration. Section 3 presents the methodology used to determine energy generated by solar and wind. In section 4 results are presented and discussed. Section 5 provides a conclusion. 


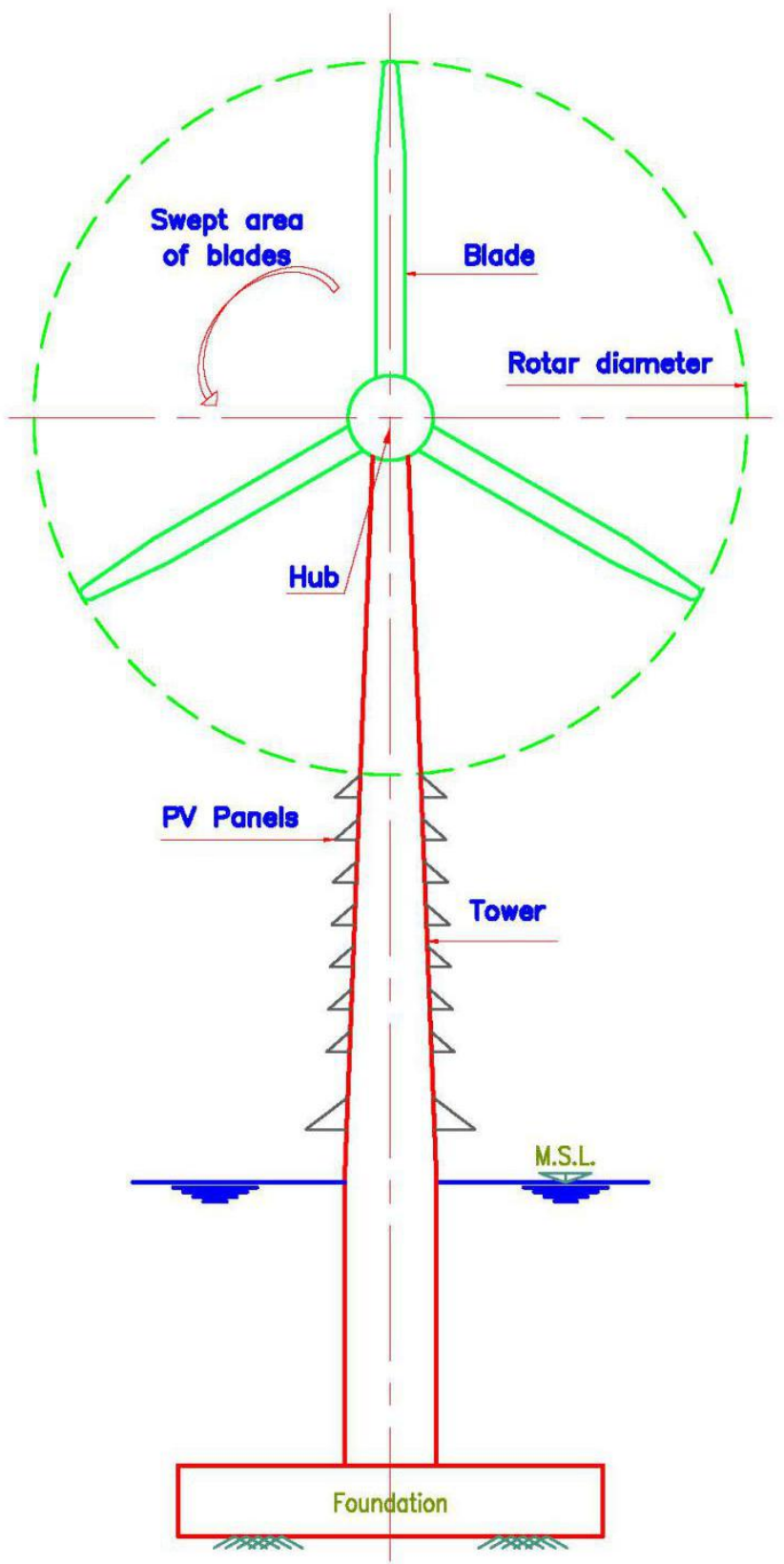

(a)

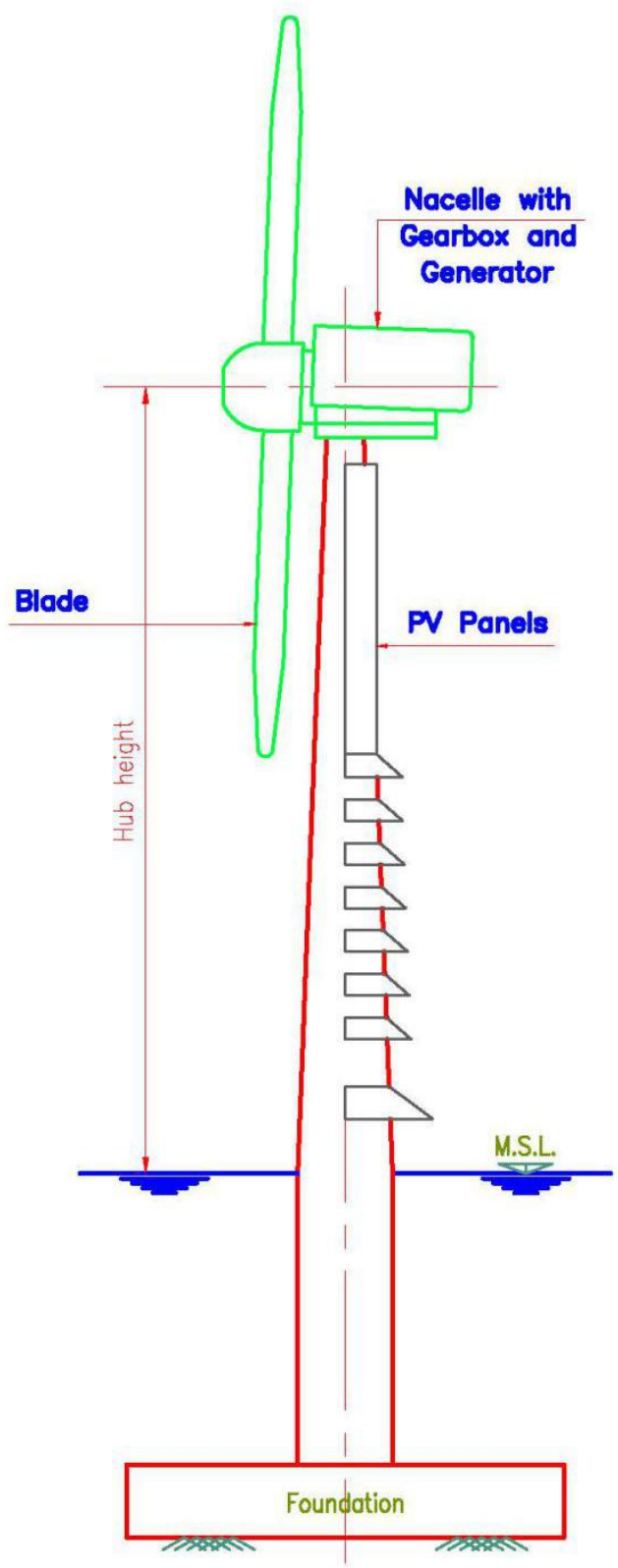

(b)

Fig. 2 : General view of HSWT (a) Front View b) Side View

\section{Combined Technology Overview}

\subsection{Objective}

With land for wind farms becoming a constraint, WT's have moved offshore with a consequent increase in costs. This has led to the concept of combining power from solar and 
wind from a single source. The hybrid power plant offers a much higher capacity factor and reduced capital costs. The combination of the two offers another key advantage in that they can harness the energy of both solar and wind power and the generation of electricity is much more constant [11]

\subsection{Project Area}

The reference project considered for this work is off the coast of Charleston (Lat, Long, $32.77^{\circ} \mathrm{N}, 79.94^{\circ} \mathrm{W}$ ), and considers 4.7 MW rated wind turbines (WT) of a $600 \mathrm{MW}$ wind farm for evaluation. The project parameters are shown in (Table1). The technical parameters for this WT are taken from the NREL Report Stehly et, al [12 ], and is intended to be representative of offshore wind projects likely to be developed in the North Atlantic region. The WT's of this project is converted to HSWT'swith the hybrid wind-solar power plant sharing an inverter and grid connection, reducing component costs due to two separate projects.

\subsection{Offshore Wind Energy}

AWT converts the kinetic energy of the wind into mechanical shaft power to drive a generator that in turn produces electrical energy. Large WT's are designed to ensure reliability, availability, maintenance, and serviceability while having the least cost of energy Dodge[13]. Detail design of a WT is outside the scope of this paper. For design guidance, a good reference is Willey [9]. Details from the reference project for a hypothetical WT are used for comparison. Wind resource for this project assumes an annual average wind speed of $8.74 \mathrm{~m} / \mathrm{sec}$ Beiter [14 ]The turbine is supported on a $100 \mathrm{~m}$ concrete tower having a fixed bottom at $30 \mathrm{~m}$ depth of water. Technical parameters for this tower are taken from Gifford[15].

Table 1 Offshore Reference Project Parameters

\begin{tabular}{cc}
\hline Project parameters & \\
\hline Turbine rated power (MW) & 4.71 \\
Number of turbines & 128 \\
Wind plant capacity (MW) & 600 \\
Water depth (m) & 30 \\
\hline
\end{tabular}




\subsection{Solar PV Plant}

Design of the solar power plant required to be integrated with the WT would require determining a) type of PV panels, b) effect of shading c) method of installation, d) size of inverters, and e) size of cabling. Presently, the five main groups of photovoltaic technologies available are crystalline silicon, cadmium telluride and cadmium sulfide, organic and polymer cells hybrid photovoltaic cells, and thin-film technology. Parida et al [16 ]. For this study, silicon, heterojunction monocrystalline panels are considered. These solar panels are mounted on the south-facing facade of the WT tower. The large curved surface area allows panels to absorb more light without needing to track the sun. Panels behind the turbine blade are mounted vertically. This is necessary as the

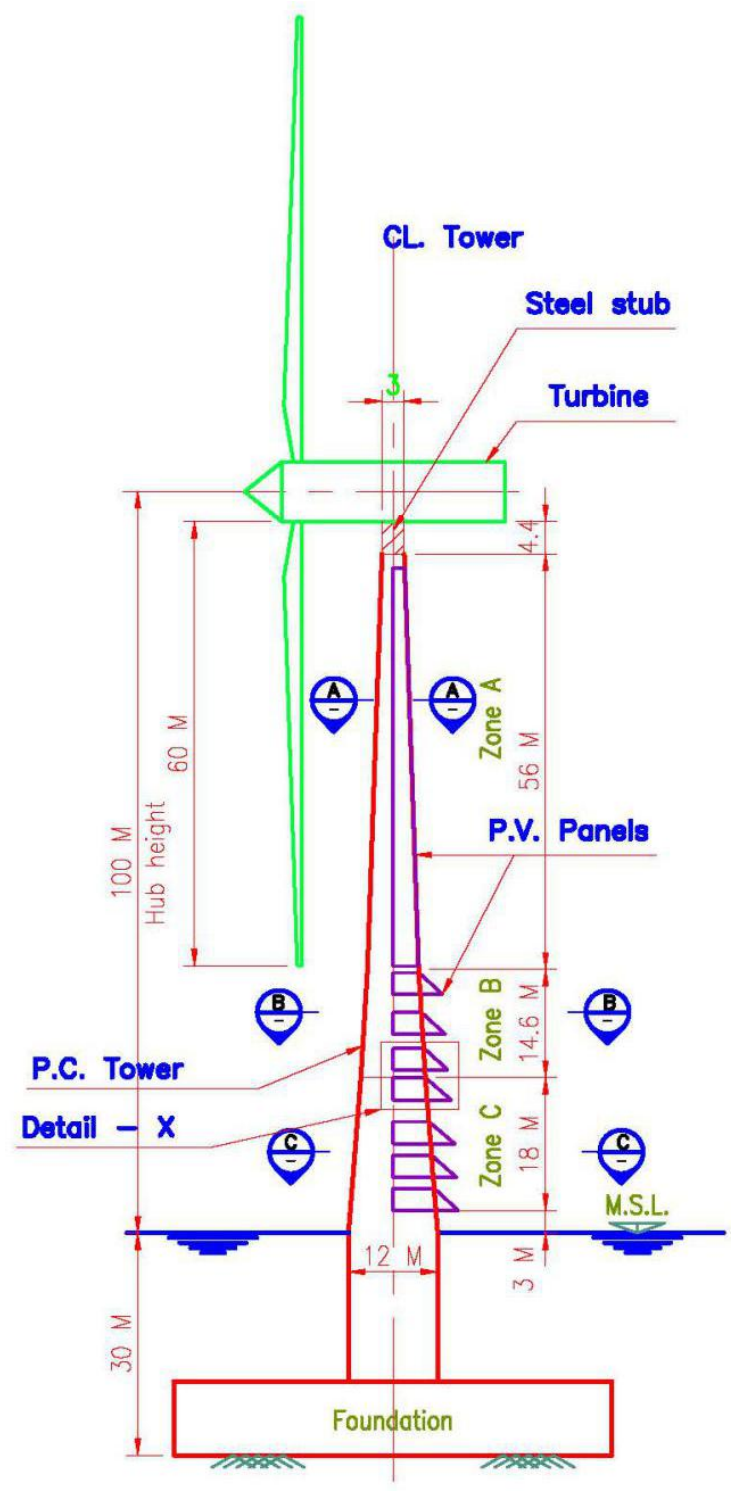

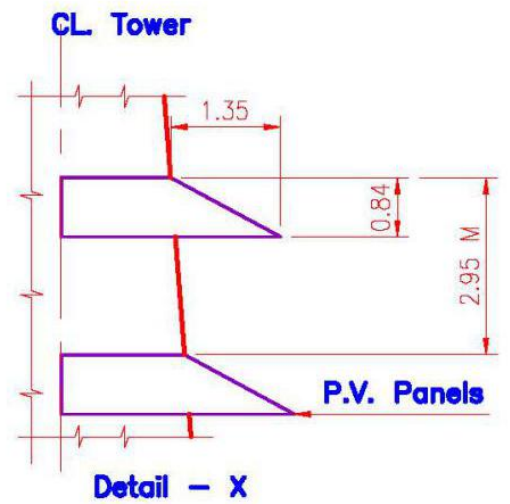

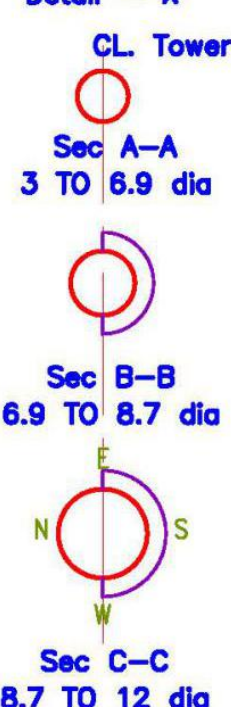

Fig. 3 : Detail of tower showing PV Panel locations 
clearance between the blade and the face of the tower has to be kept to a minimum. Generally, to avoid excessive overhang of the rotor, minimum operational blade tip clearance is kept at $1 / 3$ of static clearance or a distance of one tower radius relative to the tower diameter at the same elevation, Willey [ 9 ]. Panels located below the blade tip level are inclined to catch maximum solar irradiance based on the latitude at which WT is located. It is to be noted that the rotor of the wind turbine rotates to absorb max wind energy. In this scenario, it may be possible that the rotor faces due north and allow the south-facing panels to take full advantage of direct sunlight. See Fig 3. In the example for the calculation of energy, these two conditions have been considered

\subsubsection{Effect of shading on PV panels}

Partial shading of PV panels from the rotation of rotor blades can cause reduced efficiency of the PV array. As PV panels are made up of a string of solar cells connected in series, the current output is limited to that passing through the weakest cell. thus leading to a loss of power. Many methods have been introduced to reduce shading losses. These include by-pass diodes, different stringing arrangements, and module-level power electronics, Brown[17]. A team that includes energy company Vattenfall, research organization TNO, and e-mobility developer Heliox aims to investigate the effect of shade from WT's on the energy yield of solar parks, [18].

\subsubsection{Panel installation}

The PV panels are fixed to the tower face by inserts and racks. Towers may be of steel or concrete. The concrete towers are mostly made up of pre-fabricated shell units. To simplify transportation, these are precast in about $3 \mathrm{~m}$ tall ring units in single or multiple segments. PV panels are sized accordingly and fitted to the units so that they may be erected along with these units. For the marine environment, the connecting steel racks may be galvanized, epoxy coated, or of stainless steel.

\subsubsection{Solar-Wind hybrid integration}

Fig 4 shows a hybrid solar-wind system that is connected to an AC grid. As seen in the figure, the electricity produced by the PV array and wind turbines is inverted from DC to AC for grid connection. 


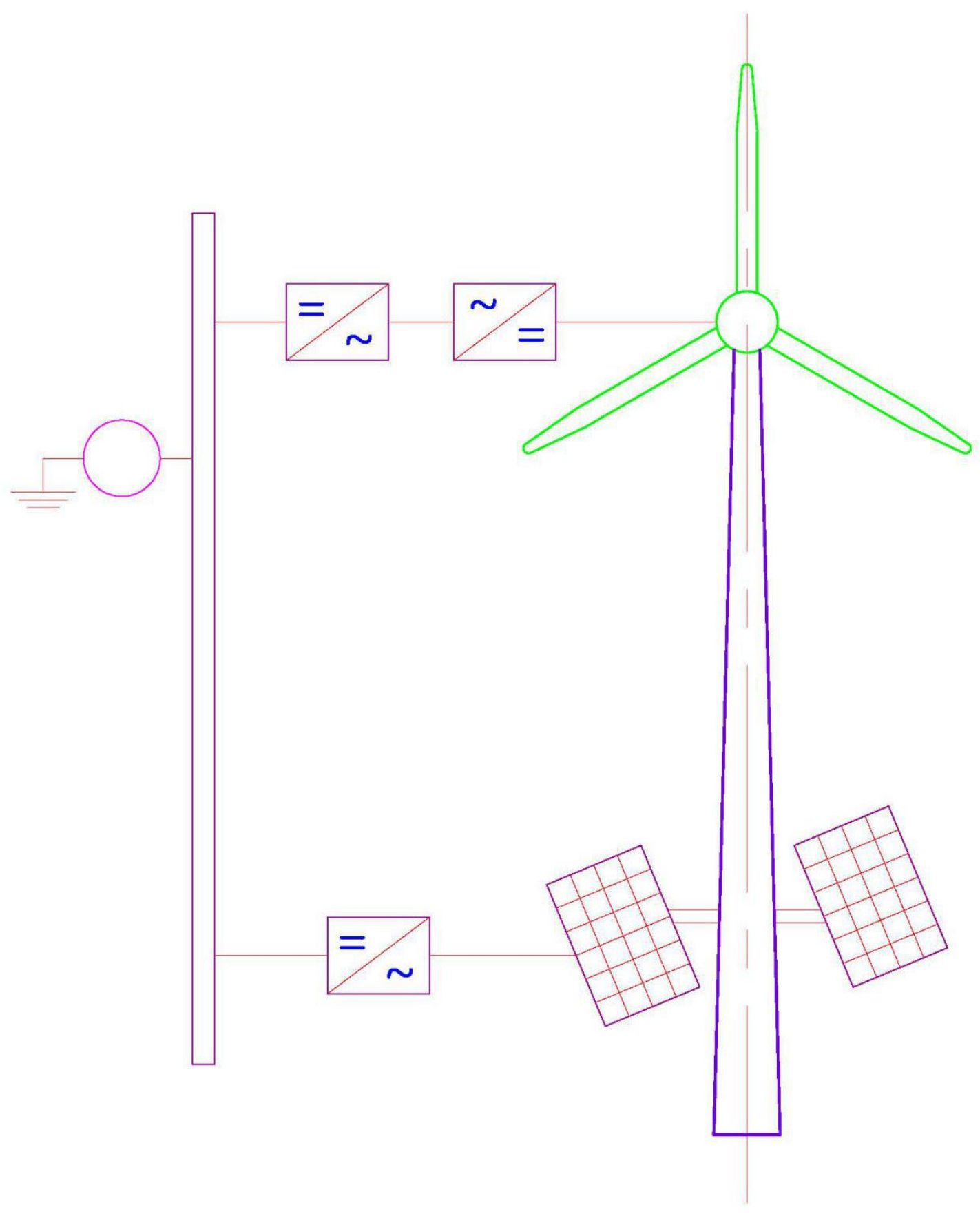

Fig. 4 : Diagram of hybrid system with AC coupling

\section{Methodology}

\subsection{Problem description}

Made as a practical design application, is a case study of 128 WT's having rated capacity 4.71 MW of a hypothetical $600 \mathrm{MW}$ wind farm located off the coast of Charleston in the 
North Atlantic. The WT is sought to be integrated with a photovoltaic solar plant and the various technical and cost issues of the HSWT are discussed.

\subsection{Preliminary system description}

A schematic configuration of the proposed design is shown in Fig. 4. In the present work, the baseline for comparing purposes is the NREL 4.7 MW WT, selected from the NREL Technical Report Stehly [12 ]. It is a conventional 3-bladed upwind utility-scale multimegawatt turbine. A similar turbine is integrated with solar panels along the tower face to convert it into an HSWT. The parameters for the target WT are shown in Table2.

Table 2 Reference Offshore Turbine Parameters

\begin{tabular}{cc}
\hline Turbine parameters & \\
\hline Turbine rated power $(\mathrm{MW})$ & 4.7 \\
Turbine rotor diameter (m) & 128 \\
Turbine hub height $(\mathrm{m})$ & 93.7 \\
Max. rotor speed $(\mathrm{m} / \mathrm{sec})$ & 90 \\
Max coeff of power & 0.47 \\
Annual avg. wind speed $(\mathrm{m} / \mathrm{sec})$ & 8.94 \\
\hline
\end{tabular}

\subsection{Solar PV plant}

\subsubsection{Solar resource}

Solar resource data for the proposed location (Lat, Long, $32.77^{\circ} \mathrm{N}, 79.94^{\circ} \mathrm{W}$ ) is based onNREL's PV Watts Model [19] and shown in Table 3. The net annual energy production is calculated using an annual average solar irradiationof $5.46 \mathrm{kWh} / \mathrm{m}^{2} /$ day.

Table 3 Solar data and Energy output at Reference site

\begin{tabular}{ccc}
\hline Month & Solar Radiation $\left(\mathrm{kWh} / \mathrm{m}^{2} /\right.$ day $)$ & AC Energy $(\mathrm{kWh})$ \\
\hline January & 4.63 & 8,346 \\
February & 4.99 & 7,976 \\
March & 5.54 & 9,729 \\
April & 6.38 & 10,719 \\
May & 6.25 & 10,644 \\
June & 5.97 & 9,797
\end{tabular}




\begin{tabular}{ccc} 
July & 5.91 & 9,972 \\
August & 5.74 & 9,679 \\
September & 5.52 & 9,038 \\
October & 5.47 & 9,403 \\
November & 4.91 & 8,357 \\
December & 4.23 & 7,630 \\
Annual & 5.46 & 111,290 \\
\hline
\end{tabular}

Source: NREL

\subsubsection{Tower and PV panel orientation}

For larger wind farms, increased size of turbines and tower height have favored the use of concrete towers, Gifford. [15].Concrete is a high-performance structural material and provides the structural strength and stiffness required for the loads and bending moments to be carried by these towers. Enercon [20 ] has developed concrete pylon designs for up to 113 $\mathrm{m}$ hub height. For this study, a prestressed concrete bi-linear tower having the configuration and indicative dimensions as indicated for a $100 \mathrm{~m}$ concrete tower supporting a $4.5 \mathrm{MW}$ turbine as tabulated in Gifford [15] is selected. Principal dimensions are shown in Fig 3. The smooth tapering south-facing facade of the pylon (section from the nacelle to the level of the highest wave crest) provides a large surface area on which the PV panels can be fixed. The conceptual design of the solar farm is defined by the type of PV panels and mounting structures. The present study has selected a $340 \mathrm{~W}$ Panasonic photovoltaic module N340HIT, [21] the technical details of which are given in Table 4. The portion of the pylon on which the PV panels are mounted is shown in Fig.3. The effective pylon height is $98 \mathrm{~m}$. The panels are fixed on the south-facing facade of

Table 4 Parameters of PV module

Panasonic Photovoltaic Module N340 HIT

$\begin{array}{cc}\text { Maximum power (W) } & 340 \\ \text { Maximum power voltage (V) } & 59.7 \\ \text { Maximum power current (A) } & 5.7 \\ \text { Open circuit voltage (V) } & 71 \\ \text { Maximum system voltage (V) } & 600\end{array}$


the pylon, starting at $5 \mathrm{~m}$ from the top and ending at $3 \mathrm{~m}$ above the highest astronomical tide level(HAT). When mounting panels, two issues need consideration: a) PV panels on tower facing turbine blade need to be installed vertically so as not to encroach the minimum tower clearance- axial distance from the blade tip to the tower, normally taken as a distance of one tower diameter relative to the tower diameter at the same elevation, Willey [9]. PV panels below the blade tip level are tilted for maximum performance. b) shading effect caused by the blade when passing in front of the panels. For a three-bladed turbine, each of the blades results in reduced irradiation reaching the panels during one complete revolution, thus resulting in loss of power.

\subsubsection{Requirement of PV panels}

To estimate the number of PV panels to be integrated at the WT level, the tower height is divided into three zones Fig. 3. Zone A, is the zone coming under the influence of the $60 \mathrm{~m}$ long rotor blade, and the PV panels are mounted vertically (tilt $90^{\circ}$ ). The effective height is taken as $55 \mathrm{~m}$. The diameter of the tower varies from $3 \mathrm{~m}$ to $6.9 \mathrm{~m}$, and the average diameter is $4.95 \mathrm{~m}$. Panels cover half the perimeter $=4.95 \times 0.5 \times 3.14=7.77 \mathrm{~m}$. Then area available $=$ $55 \times 7.77=427 \mathrm{~m}^{2}$. Area of panel $=1.67 \mathrm{~m}^{2}$. No.of PV panels in zone A $=427 / 1.67=257$. In zones $\mathrm{B} \& \mathrm{C}$, the PV panels are provided in a fixed open rack system having a tilt of $32^{\circ}$ with the horizontal, Fig. 3. To avoid self-shading, PV panel spacing is kept at $1.61 \mathrm{~m}$, to arrive at a row width of $2.45 \mathrm{~m}$. In zone $\mathrm{B}$, the tower diameter varies between $6.9 \mathrm{~m}$ to $8.2 \mathrm{~m}$, with an average diameter of $7.55 \mathrm{~m}$. Half perimeter $=11.85 \mathrm{~m}$. The number of PV panels that can be accommodated along the half perimeter $=11.85 / 1.05=11.3$ say 12 . The effective height along vertical is $19.6 \mathrm{~m}$ Then number of rows $=19.6 / 2.45=8$, and no. of panels $=8 \times 12=96$.

Similarly for zone C, the tower diameter varies between $8.2 \mathrm{~m}$ to $12 \mathrm{~m}$, with an average diameter of $10.1 \mathrm{~m}$. Half perimeter $=15.86 \mathrm{~m}$, and effective height $=18 \mathrm{~m}$. The number of PV panels that can be accommodated in zone $\mathrm{C}=7 \times 16=112$.

\subsubsection{Annual energy production from the Solar plant}

The NREL model PV Watts Calculator [19] was used to simulate the annual energy production (AEP). For the proposed location, the results gave annual solar radiation as 5.46 $\mathrm{kWh} / \mathrm{m}^{2} /$ day, based on system losses $11 \%$, inverter efficiency $96 \%$, and DC to AC ratio 1.2 . 
Referring to Fig. 3, (AEP) for HSWT with PV panels at location S, with WT rotor assumed facing $\mathrm{N}$ (no shading from the blade); For Zone A, watts capacity available is $=340 \mathrm{x}$ $257=87380 \mathrm{~W}$. Then, AEP was calculated using the PVWatts calculator [19] assuming $90^{\circ}$ tilt is $84,558 \mathrm{kWh}$. For Zones B \& C, Watts capacity $=340(96+112)=70,720 \mathrm{~W}$, and AEP assuming tilt of $32^{\circ}=111290 \mathrm{kWh}$. Typical monthly production for Zone B \&C is shown in Table 3.

For PV panels at location S, and WT rotor also at S (panels assumed under the influence of shading by the blade). Even partial shading causes loss of power in the solar cell array, Deline[22 ]. These generation losses have been assessed using the following equation for shade Impact Factor (SIF), Salih [23].

Shade Impact Factor $(\mathrm{SIF})=\left[1-\mathrm{P}_{\text {sh }} / \mathrm{P}_{\text {sys }}\right] \times \mathrm{A}_{\text {sys }} / \mathrm{A}_{\text {sh }}$

Where; $\mathrm{P}_{\text {sys }}$ and $\mathrm{A}_{\text {sys }}$ are the nominal system power and area,

$\mathrm{A}_{\text {sh }}$ is the shaded area, and $\mathrm{P}_{\text {sh }}$ power produced by panels under shaded conditions.

For a $60 \mathrm{~m}$ long blade of average width $2.25 \mathrm{~m}, \mathrm{~A}_{\mathrm{sh}}=135 \mathrm{~m}^{2} ; \mathrm{A}_{\mathrm{sys}}=427 \mathrm{~m}^{2}$; Shaded $\%=$ $135 /=28 \%$, and SIF from $[18]=0.593 ; \mathrm{P}_{\mathrm{sys}}=340 \mathrm{~W}$ Then, from Equation (1), $\mathrm{P}_{\mathrm{sh}}=138 \mathrm{~W}$. This value is approximate and final value will depend on the real-world performance of the individual panel. Watts capacity available is $=138 \times 257=35,466 \mathrm{~W}$ and AEP $=34,018$ kWh.

AEP for Zones B \& C (not affected by shading $)=111290 \mathrm{kWh}$. Total AEP for this condition is $=(34,018+111290)=145,308 \mathrm{kWh} / \mathrm{yr}$.

The power output is compatible with the low voltage current from the WT of $690 \mathrm{~V} / 3$ phase $/ 50 \mathrm{~Hz} \mathrm{AC}$.

Table 5 Comparison of the NREL 4.7 MW reference design to the combined wind and solar version of that design for the same site conditions

Condition: for no shading from the blade

\begin{tabular}{cccc}
\hline Items & & Solar & WT + solar \\
& $4.7 \mathrm{MW}$ WT & $0.158 \mathrm{MW}$ & \\
\hline CapEx $(\$ / \mathrm{kW})$ & 4579 & 940 & 5519 \\
OpEx $(\$ / \mathrm{kW} / \mathrm{yr})$ & 158 & 7 & 165 \\
Fixed charge rate $(\%)$ & 10.3 & 10.3 & 10.3
\end{tabular}


Net annual energy production( MWh/MW/yr)

\subsubsection{Costs and LCOE}

Costing is based on a rate of $0.77 \$ / \mathrm{W}_{\mathrm{DC}}$ for fix tilt utilityscale PV system taken from the 2020 Quarter NREL Technical Report [24].

For condition under no shading;

PV panels 158,100 W @ $0.77 \$ / \mathrm{W}=\$ 121,737$

Balance of System (BOS) @ 22\% $=\$ 26,782$ Sub total $=\$ 148,519$

Then costs $/ \mathrm{kW}=148519 / 158=940 \$ / \mathrm{kW}$

AC Energy pa $=195848 \mathrm{kWh} / \mathrm{yr}=196 \mathrm{MWh} / \mathrm{yr}$ or $196 / 0.158=1239 \mathrm{MWh} / \mathrm{MW} / \mathrm{yr}$

The LCOE is computed to reflect a fixed bottom offshore hybrid solar wind power plant. Based on the turbine technology parameters, wind resource, solar resource and costing, values of CapEx, FCR, OpEx, and AEP (see Table 5) are entered into the following equation to calculate LCOE,Stehly[12]

$\mathrm{LCOE}=(\mathrm{CapEx} \times \mathrm{FCR}) /(\mathrm{AEP} / 1000)+\mathrm{OpEx} /(\mathrm{AEP} / 1000)$

where:LCOE $=$ levelized cost of energy $(\$ / M W h)$

FCR $=$ fixed charge rate $(\%)$

CapEx $=$ capital expenditures $(\$ / \mathrm{kW})$

OpEx $=$ operational expenditures $(\$ / \mathrm{kW} / \mathrm{yr})$

$\mathrm{AEP}$ net $=$ net annual energy production $(\mathrm{MWh} / \mathrm{MW} / \mathrm{yrNote}: \mathrm{FCR}$ represents the amount of revenue required to pay the annual carrying charges as applied to the CapEx. Based on the assumption of a 20 years project life and discount rate of $10.5 \%$, the FCR is $10.3 \%$. Stehly [12]Then, condition under no shading for wind and solar combined;

$\mathrm{LCOE}=(5519 \times 0.103) /(4889 / 1000)+165 /(4889 / 1000)=116.2+33.7=149.9 \$ / \mathrm{MWh}$

Similarly, condition under shading for wind and solar combined;

PV panels $158100 \mathrm{~W} @ 0.77 \$ / \mathrm{W}=\$ 121,737$

Balance of System (BOS)@22\%=\$26,782Sub total=\$148,519 
Then costs $/ \mathrm{kW}=148519 / 106=1401 \$ / \mathrm{kW}$

Note: for shading, the power from PV panels is reduced, though number of PV panels remain the same.

AC Energy pa $=145308 \mathrm{kWh} / \mathrm{yr}=145 \mathrm{MWh} / \mathrm{yr}$ or $145 / 0.106=1368 \mathrm{MWh} / \mathrm{MW} / \mathrm{yrBased}$ on inputs,(Table 6)

$\mathrm{LCOE}=(5980 \times 0.103) /(5018 / 1000)+165 /(5018 / 1000)=122.7+32.88=155.6 \$ / \mathrm{MWh}$

Table 6 Comparison of the NREL 4.7 MW reference design to the combined wind and solar version of that design for the same site conditions

Condition: for shading from the blade

\begin{tabular}{cccc}
\hline Items & $\begin{array}{c}4.7 \mathrm{MW} \\
\text { WT }\end{array}$ & $\begin{array}{c}\text { Solar } \\
0.106 \mathrm{MW}\end{array}$ & WT + solar \\
\hline CapEx $(\$ / \mathrm{kW})$ & 4579 & 1401 & 5980 \\
OpEx $(\$ / \mathrm{kW} / \mathrm{yr})$ & 158 & 7 & 165 \\
Fixed charge rate $(\%)$ & 10.3 & 10.3 & 10.3 \\
Net annual energy production $(\mathrm{MWh} / \mathrm{MW} / \mathrm{yr})$ & 3650 & 1368 & 5018 \\
Net capacity factor $(\%)$ & 41.7 & 17.9 & 59.6 \\
Total LCOE $(\$ / \mathrm{MWh})$ & 173 & 111 & 156 \\
\hline
\end{tabular}

\section{Results and Discussion}

\subsection{Hybrid Solar Wind Turbine}

\subsubsection{Comparative Analysis}

Table 5shows the summarized costs for the primary components of the HSWTwith no shading. It shows that the LCOE for the combined wind turbine and solar is $150 \$ / \mathrm{MWh}$, and this is less than the LCOE of $173 \$ / M W h$ for reference wind turbines only [12]. Similarly, from Table 6, it is observed that even for the shaded condition, the LCOE of $156 \$ / \mathrm{MWh}$ is less than that of $173 \$ / \mathrm{MWh}$ for WT only [12].

The two conditions presented, one with modules under the influence of shading by blade and the other clear of the blade, represent two extreme conditions. As the nacelle revolves with the wind direction, and the PV modules are fixed in location, the effect of shading by the blade can be partial. 
The results should be considered as solely illustrative, however, as many of the elements such as wind resource, turbine characteristics, water depth, solar irradiance, solar panels, etc. will differ from site to site.

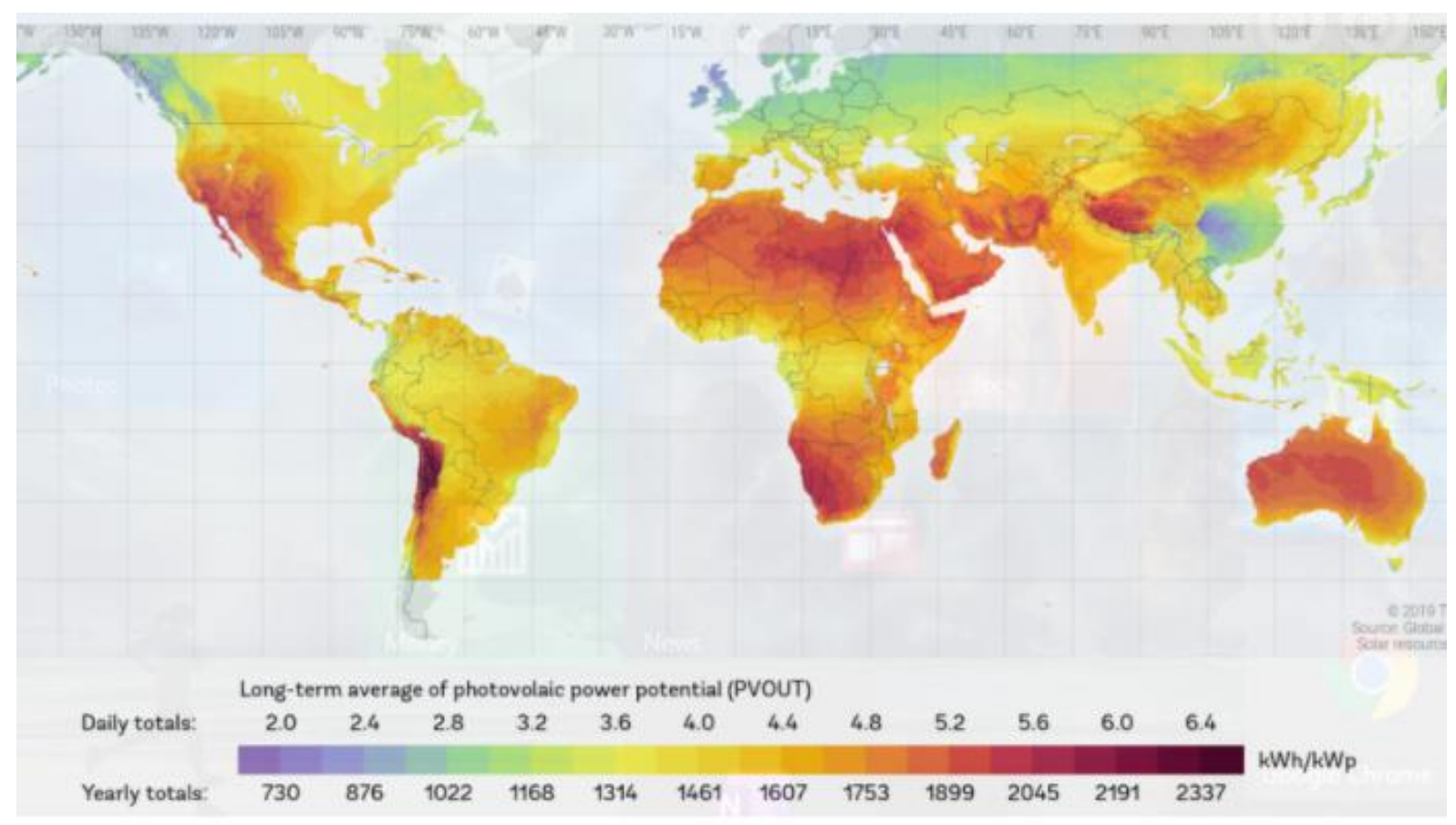

Fig. 5 Global photovoltaic power potenial

\subsubsection{Checking energy and revenue for wind farm}

The offshore reference wind farm consists of 128 WT's each rated at 4.7 MW for a total plant capacity of $600 \mathrm{MW}$, and a lifetime of 20 years.

Condition for no shading. Total energy generated by PV panels over 20 years

$\mathrm{E}=$ No of turbines $\mathrm{x}$ No. of yrs $\mathrm{x}$ energy generated by PV per turbine per annum

$\mathrm{E}=128 \times 20 \times 196=501,760 \mathrm{MWh}$. Additional revenue earned @ $0.106 \$ / \mathrm{kWh}[19]=\$$

\section{$53.18 \mathrm{~m}$}

Condition for shading; Total energy generated by PV panels $=128 \times 20 \times 145=371,200$ MWh, Additional revenue earned @ 0.106 \$/kWh NREL [19 ] = \$ 39.35 m.This may not seem much, but tangible results can only be seen when large wind farms are considered in the context of future projections for wind farms. By 2050, the capacity of wind farms for Onshore wind is set to increase to $5044 \mathrm{GW}$, and for Offshore wind by $1000 \mathrm{GW}$, IRENA [25]. This, when coupled with an unlimited supply of solar power, having a yearly PV 
potential from 737 to $2337 \mathrm{kWh} / \mathrm{kW}_{\mathrm{p}}$ Global Solar Atlas [26]. See Fig. 5, which would make the HSWT a very attractive solution in the fight for eliminating greenhouse gases.

\subsubsection{Capacity factor;}

The capacity factor of the WT is $47.1 \%$ Stehly [12] and that of the solar plant is $17.9 \%$. By combining the power from both sources, the hybrid reaches a capacity factor of $60 \%$ at a much-reduced cost.

\subsubsection{Infrastructure Development Cost;}

Utility-scale wind and solar plants are located in remote areas either on land or at sea. A hybrid power system could lead to considerable fixed capital outlay. For the present scenario, the $600 \mathrm{MW}$ wind farm could occupy an area of about $3323 \mathrm{~km}^{2}$ based on an average wind farm capacity density of $5.36 \mathrm{MW} / \mathrm{km}^{2}$, Lopez et al [27]. The additional $20 \mathrm{MW}$ from the HSWT boosts the plant capacity to $620 \mathrm{MW}$, without requiring any additional area. Further, the single grid connection point reduces overall grid investment costs and O\&M costs.

\section{Conclusions}

Hybrid solar-wind energy is receiving an increasing amount of attention because of its ability to harness both solar and wind. In this paper, a study has been carried out to assess the technical feasibility and economic viability of an HSWT that has PV panels integrated at the WT level. The hybrid's key advantage is that the two sources complement each other because the peak operating times for each system occur at different times leading to a steadier production of energy. An example is given of an offshore WT with a rated capacity of 4.7 MW and an AEP of $3650 \mathrm{MWh} / \mathrm{MW} / \mathrm{yr}$ forming part of a $600 \mathrm{MW}$ wind farm near Charleston, USA. The LCOE of this WT is compared to that of the same WT converted to an HSWT, sharing a converter and grid connection. The $100 \mathrm{~m}$ high south-facing tower of the WT to be converted is covered with 465 PV panels of $340 \mathrm{~W}$ capacity. Annual generation is $195,848 \mathrm{kWh}$ and 145,308 kWh respectively for the two conditions when PV panels are not under the influence of the blade and its influence. The LCOE's for the HSWT is 150 \$/MWh and $156 \$$ / MWh respectively. This is lower than the LCOE of 173 \$/MWh for WT only. Over its $20 \mathrm{yr}$ lifetime, the 128no. HSWT generates an income of $\$ 53 \mathrm{~m}$, and $\$ 39 \mathrm{~m}$ respectively. By combining power from both sources, the hybrid reaches a capacity factor of $60 \%$.In conclusion, HSWT would help to make wind farms a more cost-effective and 
competitive source of clean energy. However, more work needs to be done to make it technically feasible and deployable.

\section{References}

[1] Scott Brownhttps://www.renewableenergymagazine.com/wind/strategic-alliance-toproduce-a-groundbreaking 10th Oct 2011

[2] Combined Floating Offshore Wind and Solar PVMario López, Noel Rodríguez and Gregorio Iglesias ,http://www.mdpi.com/journal/jmse 30 July 2020

[3] https://en.wikipedia.org/wiki/Gujarat_Hybrid_Renewable_Energy_Park

[4] Tina, G., Gagliano, S., and Raiti, S. "Hybrid solar/wind performance assessment", Solar Energy, Vol. 80, pp. 578-588, 2006

[5] Kershman, S.A., Rheinlander, J., Neumann, T., andGoebel, O. "Hybrid Wind/PV and Conventional Power ForDesalination In Libya - GECOL Facility For Medium And Small Scale Research At Ras Ejder”, Desalination, Vol.183, No. 1-3, pp. 1-12, 2005.

[6] Celik, A.N. "Techno-Economic Analysis Of AutonomousPV-Wind Hybrid Energy Systems Using Different SizingMethods”, Energy Conversion And Management, Vol. 44, pp. 1951-1968, 2003.

[7] Bakos, G.C., and Tsagas, N.F. "Techno-economic assessment Of A Hybrid Solar/Wind Installation ForElectrical Energy Saving”, Energy and Buildings, Vol. 35, No. 2, pp. $139-45,2003$

[8] Deshmukh, M.K., Deshmukh, S.S. "Modeling Of hybrid renewable Energy Systems", Renewable and Sustainable Energy Reviews, Vol. 12, No. 1, pp. 235-249, 2008

[9] Lawrence D. Willey Design and development of megawatt wind turbines WIT Transactions on State of the Art in Science and Engineering, Vol 44, (C) 2010 WIT Pressdoi:10.2495/978-1-84564-205-1/06

[10] (https://kohilowind.com/kohilo-university/202-types-of-wind-turbines-their-advantagesdisadvantages/

[11] http://energy.gov/energysaver/articles/hybrid-wind-and-solar-electric-systems July 2012

[12] Tyler Stehly, Donna Heimiller, and George Scott 2016 Cost of Wind Energy Review Technical ReportNREL/TP-6A20-70363 December 2017, www.nrel.gov/publications 
[13] Dodge, D.M., Illustrated History of Wind Power Development, Littleton, Colorado, 1996 - 2005. http://www.telosnet.com/wind/index.html

[14] Beiter, P., W. Musial, L. Kilcher, M. Maness, A. Smith. 2017. An Assessment of the Economic Potential of Offshore Wind in the United States from 2015 to 2030 (Technical Report), NREL/TP-6A20-67675. National Renewable Energy Laboratory (NREL), Golden, CO (US).

[15] GiffordConcrete Towers for Onshore and Offshore Wind Farms, www.concretecentre.com ISBN 1-904818-48-X, 2017

[16] Parida, B.; Iniyan, S.S.; Goic, R. A review of solar photovoltaic technologies. Renew. Sustain. Energy Rev.2011, 15, 1625-1636. [CrossRef

[17] Christian Brown Shading Losses in PV systems, and Techniques to mitigate them https://www.aurorasolar.com/blog/shading-losses-for-pv-systems-and-techniques-tomitigate-them/

[18] The research investigates the shady role of wind turbineshttps://www.energylivenews.com/2021/11/02/research-investigates-the-shadyrole-of-wind-turbines/

[19] NREL (National Renewable Energy Laboratory), 2017. PV Watts Calculator.<http:// vwatts.nrel.gov>

[20] Enercon GmbH, Tower Versions, 2004. Available from: www1.enercon.de

[21] Panasonic https://na .panasonic.com/us/solar support?series $=778018$ product $=62766$

[22] C. Deline Partially shaded operation of a grid-tied PV system Conference Paper NREL/CP-520-46001 June 2009 https://www.nrel.gov/docs/fy09osti/46001.pdf

[23] Salih Mohammed Salih, Mohammed Qasim Taha Analysis of Shading Impact Factor for Photovoltaic Modules https://www.researchgate.net/publication/273773634

[24] us solar photovoltaic system cost benchmark 2020 Technical Report NREL/TP-6A2077324 Jan 2021 https:/www.nrel.gov/docs/fy21osti/77324.pdf

[25] Future of Wind - A Global Energy Transformation paper -IRENA https://www.irena.org//media/Files/IRENA/Agency/Publication/2019/Oct/IRENA_Future_of_wind_2019.pdf https:/www.nrel.gov/docs/fy17osti/67675.pdf.

[26] Global Solar Atlas - Wikipediaen.wikipedia.org > wiki > Global_Solar_Atlas

[27] Mario López 1 , Noel Rodríguez 1 and Gregorio IglesiasCombined Floating O_shore Wind and Solar PVJ. Mar. Sci. Eng. 2020, 8(8), 576; https://doi.org/10.3390/jmse8080576 